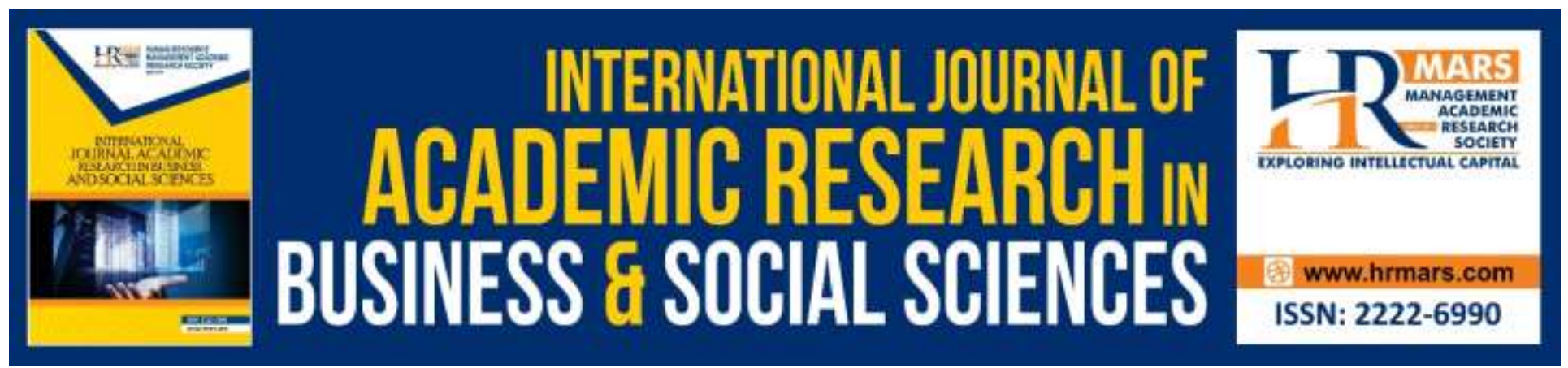

\title{
The Relationship of the Democratic Leadership style with the Job Satisfaction of Faculty Members in Private Universities in Jordan
}

Hafsa Yahea Aljamal, Najihah Abd Wahid

To Link this Article: http://dx.doi.org/10.6007/IJARBSS/v10-i6/7356

DOI:10.6007/IJARBSS/v10-i6/7356

Received: 25 April 2020, Revised: 29 May 2020, Accepted: 10 June 2020

Published Online: 28 June 2020

In-Text Citation: (Aljamal \& Wahid, 2020)

To Cite this Article: Aljamal, H. Y., \& Wahid, N. A. (2020). The Relationship of the Democratic Leadership style with the Job Satisfaction of Faculty Members in Private Universities in Jordan. International Journal of Academic Research in Business and Social Sciences, 10(6), 696-705.

Copyright: (c) 2020 The Author(s)

Published by Human Resource Management Academic Research Society (www.hrmars.com)

This article is published under the Creative Commons Attribution (CC BY 4.0) license. Anyone may reproduce, distribute, translate and create derivative works of this article (for both commercial and non-commercial purposes), subject to full attribution to the original publication and authors. The full terms of this license may be seen

at: http://creativecommons.org/licences/by/4.0/legalcode

\section{Vol. 10, No. 6, 2020, Pg. 696 - 705}

Full Terms \& Conditions of access and use can be found at http://hrmars.com/index.php/pages/detail/publication-ethics 


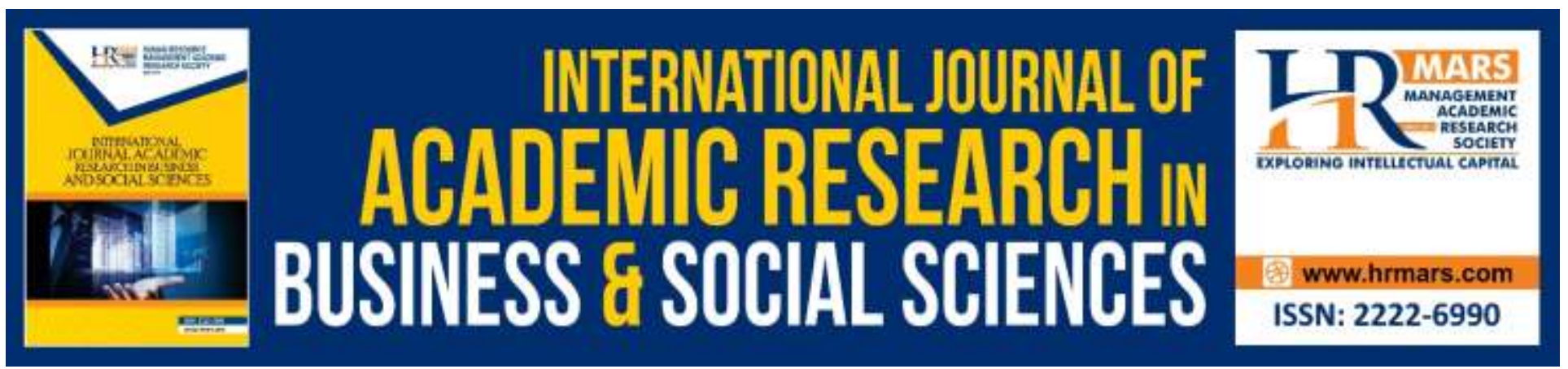

\title{
The Relationship of the Democratic Leadership style with the Job Satisfaction of Faculty Members in Private Universities in Jordan
}

\author{
Hafsa Yahea Aljamal, Najihah Abd Wahid \\ Faculty of Contemporary Islamic Studies, Universiti Sultan Zainal Abidin, \\ 21030 Kuala Nerus, Terengganu \\ Email: Hafsa.aljamal@yahoo.com, anajihah@unisza.edu.my
}

\begin{abstract}
This paper aims to reveal the relationship of the democratic style of faculty deans with the job satisfaction of faculty members in private universities in Jordan. To achieve the goals of the study, the study instrument was developed to measure the job satisfaction of faculty members in those universities, and the questionnaire was distributed to the study sample in a random and systematic manner, which consists of (345) members. The study concluded that there is a positive relationship between the style of democratic leadership and the job satisfaction of the faculty members.
\end{abstract}

Keywords: Democratic Leadership Style, Job Satisfaction, Leadership.

\section{Introduction}

Higher education is a leader of the movement for progress and civilized prosperity in all fields, and accordingly, states have their hopes and aspirations suspended in achieving the highest civilizational and material horizons. Higher education is one of the most important means for developing society politically, economically and socially, because it means developing the human being who represents the most valuable resource in any society (Arabiyat, 2012 ). Universities are considered centers of intellectual and research radiation in societies that play important roles, interact with the surrounding environment and influence and be affected by them, as the university system is distinguished from other other bureaucratic systems, which requires that the university be managed with a leadership philosophy and administrative style that is consistent with the characteristics of the university system. Where job satisfaction is considered to be the primary concern in all strategies, as it is the bridge that achieves efficiency, as research and study is shown by researchers in particular and educational leaders in general for various reasons, so what the individual currently satisfies may not satisfy him in the future.

The university is a complex institution with distinct goals, in which officials undertake tasks of a special scientific nature, and they take multiple paths in these universities (Al-Mikhlafi, 2009). 
INTERNATIONAL JOURNAL OF ACADEMIC RESEARCH IN BUSINESS AND SOCIAL SCIENCES Vol. 10, No. 6, June, 2020, E-ISSN: 2222-6990 @ 2020 HRMARS

In order to, achieve job satisfaction for them. We must here be certain of the great role that decisionmakers in these universities, especially the deans of faculties, will have on them, because of their effectiveness in achieving job satisfaction for their faculty members, by exercising leadership styles and creative skills in managing. The work of the faculty, which is the nucleus of education in any university, and the extent of the results of that deans of faculties achieve results through the exercise of a leadership style in achieving job satisfaction for the faculty members working for him in light of financial developments and alleviating the surrounding pressures that affected the faculty member in that Universities.

\section{Terminology of Study}

Leadership represents the process of influencing individuals and groups in order to, direct them towards achieving the objectives of the organization, and this has led to recognition of the importance of leadership as an essential and important factor in the organization.

Eliwa (2001), believes that leadership is a practice for the organization's administrative leader in the area of decision-making and issuance, orders and administrative supervision, and the use of official authority, and through influences, with the intention of achieving a specific goal. Al-Harahsheh (2010) says that a leadership style is a repetitive and characteristic behavior of a person.

The importance of the leadership style followed by the leader in knowing the most effective leadership styles in achieving the goals of higher education institutions according to what he sees (AlMishaal, 2006). These stylies are:

A. Democratic style: It is a collective action so that the decision is taken collectively. This style depends on the affection and mutual trust between the leader and subordinates and creating a spirit of cooperation between them while preserving the leader's entity and respecting his capabilities.

B. Autocratic style: In this style the leader is unique in setting policies and making decisions and forcing subordinates to implement his decisions.

C. Free style: In this style, the leader leaves his subordinates responsibility and freedom to act, so he does not participate with them in taking the decision, and each subordinate performs his work in the manner that suits him.

In this paper, the democratic leadership style will be measured with the job satisfaction of faculty members.

Job satisfaction: It is a positive self-feeling carried by the employee during the performance of his work, and this is achieved by reconciling what one expects from his work and the amount of what he actually gets in this work in order to satisfy his needs and expectations in his work environment (brea'h, Moussaoui 2016).

The job satisfaction of the employees in any institution or organization is considered one of the most important factors that modern departments seek and the dependent variable that the administration is targeting in most of its strategies, as it is the link through which the efficiency and merit of the organization is achieved, and it is also considered a subject that should remain subject to research and study from time to time For leaders, for many reasons for example, what the individual today will not satisfy in the future, and what is considered satisfactory today may not be satisfactory in the future, and is also considered the main supporter for raising performance, so when the worker is not satisfied with the working environment in all its forms, he cannot fully perform his duties even if he is subject to punishment, but when the worker is satisfied with his work, he does his job in the best way, and the results of the work are more creative (Al-Dosari, 2013). 
INTERNATIONAL JOURNAL OF ACADEMIC RESEARCH IN BUSINESS AND SOCIAL SCIENCES Vol. 10, No. 6, June, 2020, E-ISSN: 2222-6990 @ 2020 HRMARS

In order to, achieve job satisfaction for them, we must here be certain of the great role that decisionmakers in these universities, especially the deans of faculties, will have on them because of their effectiveness in achieving job satisfaction for their faculty members, by exercising leadership styles and creative skills in managing. The work of the faculty, which is the nucleus of education in any university, and the extent of the results of that deans of faculties achieve results through the exercise of a leadership style in achieving job satisfaction for the faculty members working for him in light of financial developments and alleviating the surrounding pressures that affected the faculty member in that Universities. Hence the problem of the study, which will be shed light to know the relationship of the democratic leadership style practiced by the dean of the faculty in order to, achieve job satisfaction for a faculty member in private universities in Jordan.

Objective 1: Studing the relationship between the democratic leadership style practiced by the dean of the faculty to achieve job satisfaction for faculty members in private universities in Jordan.

\section{Theoretical Framework}

Job satisfaction for any management is a concern in all strategies, as it is the bridge that achieves efficiency, as research and study is shown by researchers in particular and educational leaders in general for various reasons, so what the individual currently satisfies may not satisfy him in the future and vice versa (Dai's, 2016).

Many literatures reviewe, have shed light on this variable due to its importance in achieving many aspects of any educational, commercial or other establishment. Where Mansour (2010) conducted a study aimed at identifying the degree of job satisfaction of the faculty members at An-Najah National University, and the study variables were the effect of the qualifications variable and experience on that, and the study sample consisted of (138) members of the faculty, and the questionnaire was applied on them, the researcher used the Descriptive survey methodology, and the most important results were transformed in that the degree of job satisfaction was an average degree, and the study of Milod (2017), to address job satisfaction and its impact on teacher performance, as this study compares between the teacher in the government school and the private school, and has dealt Job satisfaction from moral, social and family aspects and trying to link it to his performance of his work. Young (1994), who aimed to find out the leadership style of faculty deans and their impact on job satisfaction for faculty members, which he undertook in the Mississippi region, where the researcher used two measures the first to measure the level of leadership style followed by deans and the second to measure job satisfaction for faculty members in the faculty, the study sample was (94) faculty members, and the study found a statistically significant relationship between the leadership style of faculty heads and job satisfaction among faculty members, and as Al-Shamrani (2016) conducted, a research in which he sought to find out the relationship between the leadership style of the deans of faculties of "Education University of Shaqra" from the viewpoint of faculty members, so that the study sample consisted of (66) faculty members, and the researcher relied on two measures, one of them to measure the leadership style and the other to measure the achievement batch, and the research reached that the democratic style is the highest in the levels of the three leadership styles from one point the consideration of faculty members.

The first hypothesis: There is a positive relationship between the democratic leadership style and job satisfaction of the faculty members in private universities in Jordan from the viewpoint of its faculty members. 
INTERNATIONAL JOURNAL OF ACADEMIC RESEARCH IN BUSINESS AND SOCIAL SCIENCES

Vol. 10, No. 6, June, 2020, E-ISSN: 2222-6990 @ 2020 HRMARS

\section{The Explaining Theory \\ Needs Theory}

This theory is the conclusion of Maslow in the year (1945), this theory explain that the motives of the individual working in the work are not measured by economic and social motives only, but there are higher motives than that which are no less important in their impact on the behavior of the individual in another sense on his job satisfaction. In general a set of assumptions has been made that govern this theory, the most important of which is that a person is in constant need and that his need affects his behavior and the unpopular needs are the influences on behavior.

\section{Methodology}

The study used the relational descriptive methodology, by the relational descriptive methodology is applied if the purpose of the study is to know whether or not there is a relationship between two or more variables (Obeidat et al., 2005). Correlational studies aim to discover and describe the strength of the link between the various variables (Abdel-Qader, 2011), and defines (Al-Assaf, 2000), the descriptive, relational methodology as that type of research method by which it is possible to know whether there is a relationship between two or more variables, and who then knowing the degree of that relationship as shown by the study of Nani and Adly (2017), which aimed to reveal the relationship between leadership styles and organizational creativity and the study of Zakaria (2017), which aimed to identify the degree of satisfaction of faculty members with the performance of scientific councils at the" University of Najran".

This study has developed a special questionnaire, in order to identify the impact of the leadership behavior of deans of faculties in private universities on the job satisfaction of faculty members from the viewpoint of them in those universities where the instrument consisted of its final form of three parts, the first part to briefly identify the respondent with the aims of the study And its terms, and the second part includes preliminary data on the sample population represented in the data of demographic variables (academic rank, years of experience, gender). As for the third part of the questionnaire, it consists of three main axes:

The axis of leadership styles, and it has three dimensions, which are the democratic style, the autocratic style, and the free style. The axis of job satisfaction.

The current study questionnaire was presented with 4 reviewers with experience and expertise in the field of management and education in order to review the instrument to ensure its authenticity. This study was applied to the 346 faculty members in private universities in Jordan. The researcher distributed 390 questionnaires to the study sample, it was found that the number of unresponsive is 25 members with a response rate of $93.5 \%$. And also it was found that 19 questionnaires were not properly packed by the respondents. Thus, the total number of questionnaires valid for analysis is 346 (study sample).

\section{Questionnaire's Reliability}

The "Cronbach's Alpha" test was used. It measures the consistency of the respondents answers to all the questions on the scale. "Cronbach Alpha" can be interpreted as the coefficient of internal stability between answers, and the higher its value, the higher the degree of stability where the value is high if it is greater than (80\%) and medium if it is between (70\%-80\%) and low if it is less than (65\%) (Gujarati, 2004), it is clear from (Table. 1) that the values of coefficients ranged from weakness to 
INTERNATIONAL JOURNAL OF ACADEMIC RESEARCH IN BUSINESS AND SOCIAL SCIENCES Vol. 10, No. 6, June, 2020, E-ISSN: 2222-6990 @ 2020 HRMARS

strength, and this indicates that the study instrument was well diversified when taking the opinions of the respondents.

Table. 1: The Reliability Results

\begin{tabular}{|l|l|l|}
\hline section & No. questions & $\begin{array}{l}\text { Cronbach } \\
\text { Alpha }\end{array}$ \\
\hline $\begin{array}{l}\text { A measure of democratic leadership style for } \\
\text { deans aculty }\end{array}$ & 21 & 0.814 \\
\hline Jop satisfaction measure for faculty members & 18 & 0.899 \\
\hline Total questionnaire questions & 39 & 0.8565 \\
\hline
\end{tabular}

\section{The Results of The Study}

\section{Results related to the Democratic Leadership Scale}

The independent variable (democratic leadership style) was studied with the dependent variable (job satisfaction). According to the results shown in Table. 2, it shows the results of mean, standard deviations, upper and lower values, and degrees of approval for a measure of democratic leadership style for faculty deans in private universities in Jordan.

Table. 2: Descriptive Analysis (Democratic Leadership Scale)

\begin{tabular}{|l|l|l|l|l|l|}
\hline no & statement & Minimum & Maximum & Mean & $\begin{array}{c}\text { Std. } \\
\text { Deviation }\end{array}$ \\
\hline 1 & $\begin{array}{l}\text { treats his colleagues with } \\
\text { transparency and clarity. }\end{array}$ & 1 & 5 & 4.34 & 0.94 \\
\hline 2 & $\begin{array}{l}\text { The principle of flexibility } \\
\text { applies in applying laws and } \\
\text { regulations. }\end{array}$ & 1 & 5 & 4.14 & 0.96 \\
\hline 3 & $\begin{array}{l}\text { Faculty members are } \\
\text { involved in the decision- } \\
\text { making process. }\end{array}$ & 1 & 5 & 4.20 & 0.93 \\
\hline 4 & $\begin{array}{l}\text { It accommodates the } \\
\text { university's requirements } \\
\text { and the needs of the aculty } \\
\text { members. }\end{array}$ & 1 & 5 & 4.30 & 0.86 \\
\hline 5 & $\begin{array}{l}\text { Faculty members are allowed } \\
\text { to take a leadership role. }\end{array}$ & 1 & 5 & 4.05 & 0.93 \\
\hline 6 & $\begin{array}{l}\text { Trying to achieve justice as } \\
\text { possible among the faculty } \\
\text { members. }\end{array}$ & 1 & 5 & 4.26 & 1.06 \\
\hline 7 & $\begin{array}{l}\text { The method of dialogue and } \\
\text { discussion takes a method to } \\
\text { solve the problems of faculty } \\
\text { members. }\end{array}$ & 1 & 5 & 4.23 \\
\hline Democratic leadership style. total mean: 4.22, total Std. Deviation: 1.96 & \\
\hline
\end{tabular}


INTERNATIONAL JOURNAL OF ACADEMIC RESEARCH IN BUSINESS AND SOCIAL SCIENCES Vol. 10, No. 6, June, 2020, E-ISSN: 2222-6990 @ 2020 HRMARS

It is clear from Table. 2, and from the results of the analysis, that the democratic leadership style exercised by the Dean of the faculty over the faculty members in these universities was the mean (4.22) and the standard deviation (0.96).

Therefore, it's clear that the democratic style followed by the deans of faculties has a direct and significant positive relationship in achieving job satisfaction for faculty members in private universities in Jordan. Where the statment "deals with his colleagues in full transparency and clarity" got the highest rank in an arithmetic mean (4.34) and with a standard deviation (0.94), while the statment "faculty members are allowed to take a leadership role" got the last rank with an arithmetic mean (4.05) and with a standard deviation (0.93). Therefore, the deans of faculties practicing the democratic style was high.

\section{Results related to job satisfaction scale}

It is clear from Table. 3 the results of the mean, standard deviations, upper and lower values and the approval scores for the job satisfaction scale for faculty deans in private universities in Jordan.

Table. 3: Descriptive Analysis (job satisfaction scale)

\begin{tabular}{|l|l|l|l|l|l|}
\hline no & statement & Minimum & Maximum & Mean & $\begin{array}{c}\text { Std. } \\
\text { Deviation }\end{array}$ \\
\hline 1 & $\begin{array}{l}\text { I feel responsible for the } \\
\text { university to which I } \\
\text { belong. }\end{array}$ & 1 & 5 & 4.93 & 0.67 \\
\hline 2 & $\begin{array}{l}\text { My relationship is good } \\
\text { with My colleagues in the } \\
\text { work. }\end{array}$ & 1 & 5 & 4.92 & 0.59 \\
\hline 3 & $\begin{array}{l}\text { My work offers me many } \\
\text { opportunities to acquire } \\
\text { new skills and } \\
\text { experiences. }\end{array}$ & 1 & 5 & 4.51 & 0.77 \\
\hline 4 & $\begin{array}{l}\text { I do work commensurate } \\
\text { with the nature of my } \\
\text { work. }\end{array}$ & 1 & 5 & 4.37 & 0.80 \\
\hline 5 & $\begin{array}{l}\text { My work creates a social } \\
\text { status for me and my } \\
\text { ambitions. }\end{array}$ & 1 & 5 & 4.37 & 0.87 \\
\hline Job satisfaction scale. total mean: 4.62 total Std. Deviation: 0.74 & \\
\hline
\end{tabular}

From Table. 3, it appears that the sum for both the mean (4.62) and the deviation (0.74). It appears that faculty members have job satisfaction.

\section{Test of Normality}

The study used a test of normal distribution of all variables, where the values of Skewness and Kurtosis were used. The data are subject to normal distribution if the Skewness values are less than 3 and the Kurtosis values are less than 10. Table. 4 indicates the results of the normal distribution test for the study variables: 
INTERNATIONAL JOURNAL OF ACADEMIC RESEARCH IN BUSINESS AND SOCIAL SCIENCES Vol. 10, No. 6, June, 2020, E-ISSN: 2222-6990 @ 2020 HRMARS

Table. 4: Test of Normality

\begin{tabular}{|l|l|l|l|l|}
\hline \multirow{2}{*}{ Axis } & \multicolumn{3}{|l|}{ Kurtosis } & Skewness \\
\cline { 2 - 5 } & $\begin{array}{l}\text { Statistical } \\
\text { value }\end{array}$ & $\begin{array}{l}\text { Random } \\
\text { error }\end{array}$ & $\begin{array}{l}\text { Statistical } \\
\text { value }\end{array}$ & $\begin{array}{l}\text { Random } \\
\text { error }\end{array}$ \\
\hline $\begin{array}{l}\text { Democratic leadership } \\
\text { style }\end{array}$ & $0.055-$ & 0.355 & $0.443-$ & $0.179-$ \\
\hline Jop satisfaction & 0.215 & 0.355 & $0.615-$ & 0.179 \\
\hline
\end{tabular}

Table. 4 indicates that all Skewness values were less than 3 as the highest value $(-0.615)$ of the job satisfaction axis, while Kurtosis, all values were less than 10 . These results indicate that all study variables are safe from normal distribution problems.

\section{Regression Analysis}

The linearity of the regression model test indicates that the relationship between the independent variable and the dependent variable is linear, and this relationship is tested by $\boldsymbol{P}$-P $\boldsymbol{P l o t}$ for the rest of the regression model as indicated (Gujarati, 2004). The following figure shows the results of the linearity of the regression model. Figure. 1 illustrates this:

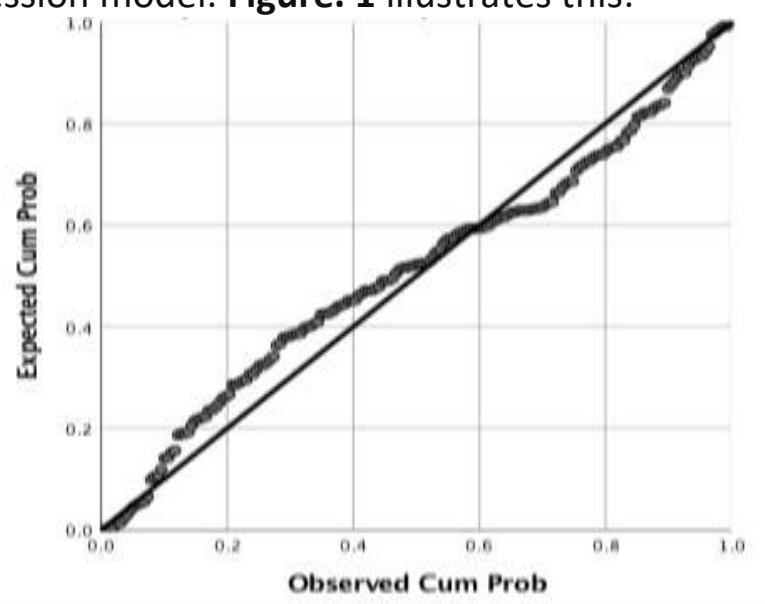

\section{Conclusions and Recommendations}

This study is one of the few studies conducted in this context, in general in Jordan and in particular on private universities. Consequently, this study supports the literature review dealing with such a situation which dealt with a leadership style to achieve job satisfaction. In the end, the results of the study that was reached, this study presents the following recommendations and suggestions:

A. Strengthening the democratic leadership style prevailing in universities, and urged deans of colleges to follow it because of its positive impact on achieving job satisfaction for faculty members in private universities in Jordan

B. Giving job satisfaction great attention to all who practice leadership and constantly, because achieving job satisfaction for workers in general and faculty in particular leads to achievement and development.

\section{Contribution of the Study}

The importance of this study will lie in contributing to: 
INTERNATIONAL JOURNAL OF ACADEMIC RESEARCH IN BUSINESS AND SOCIAL SCIENCES

Vol. 10, No. 6, June, 2020, E-ISSN: 2222-6990 @ 2020 HRMARS

1. Improve the quality, efficiency and effectiveness of university education outcomes in private universities in Jordan and by practicing the democratic leadership style of faculty deans.

2. Providing libraries with knowledge by identifying leadership styles that affect job satisfaction.

3. It is a reference for researchers and those interested and provides them with the means for further studies. 4. It helps decision-makers to improve, develop and advance the level of job satisfaction through following the most effective leadership style (democratic style).

\section{References}

Abd-al-Qadir, M. A., Abu-Qalla, M. M., and, Al-Muhairah, M. S (2012). The prevailing leadership styles and its relationship to the dimensions of the quality of education, Baghdad University College Journal of Economic Sciences. No. 33, p.95-128.

Al-Dossary, H. B. M., Hamed, F. M., Tarawneh, T. A. M., and Al-Hindi, W. M. (2013). Leadership patterns and their relationship to job satisfaction in the College of Technology in Al-Kharj from the viewpoint of employees (Doctoral dissertation).

Al-Harahisha, A., and al-Smadi, S. (2001). Bureaucracy and its role in building administrative institutions, (1 $1^{\text {st }}$ edition), Amman: Dar Al Khaleej for Publishing and Distribution.

Al-Meshal, N. H. (2006). Leadership styles among principals in the primary stage for girls in Riyadh and their relationship to the job satisfaction of female teachers, Master Thesis, Riyadh, Imam Muhammad bin Saud Islamic University.

Al-Mikhlafi, M. V. (2009). Educational administrative leadership in higher education institutions, $\left(1^{\text {st }}\right.$ edition), Amman: Zahran Publishing House.

Al-Shamrani, H. M. (2016). The prevailing leadership style among the deans of the Faculties of Education at Shaqra University as viewed by faculty members as a field study. The International Educational Journal Specialized. Volume 5, No. 11, p.77-88.

Arabiyat, B. (2016). The prevailing patterns of educational leadership among the heads of academic departments at Al-Balqa Applied University, and its impact on the job performance of faculty members (College of Technology Engineering case study). Journal of the Islamic University of Educational and Psychological Studies, 20 (2).

Bryah, M. A., and Moussaoui, Y. (2016). The effect of job satisfaction on the performance of human resources. A case study of the public hospital hospital in Maghnia. Master Thesis, Abi Bakr University Belkaid Tlemcen.

Elwa, E. (2001). Leadership development for new managers. (1 $1^{\text {st }}$ edition). Dar Al Samah: Cairo.

Gujarati, D. N., \& Porter, D. C. (2004). Basic econometrics (ed.). Mc Graw-Hill. Irwin, a business.

Mansour, M. M. (2010). The degree of job satisfaction among the faculty members at An-Najah National University in Palestine. Al-Azhar University Journal in Gaza, Humanities Series, Volume 12, No. 1. P.55-72.

Miloud, M., and Abdul-Karim, S. (2017). Job satisfaction and its effect on teacher performance. A comparative study between the teacher in the public school and the teacher in the private school in Wilaya of Djelfa. Master Thesis, University of Xian Ashour Jafleh (unpublished).

Nani, N., and Adly, M. (2017). The relationship between leadership styles and administrative creativity (a field study of the company specialized in manufacturing ECO corrugated paper covers in Blida, Algeria, University of Blida.

Obaidat, T. (2000). Scientific Research, its Concept, instrument, Methods. (1 ${ }^{\text {stedition}), ~ O s a m a ~}$ Publishing : Amman, Jordan. 
INTERNATIONAL JOURNAL OF ACADEMIC RESEARCH IN BUSINESS AND SOCIAL SCIENCES

Vol. 10, No. 6, June, 2020, E-ISSN: 2222-6990 @ 2020 HRMARS

Zakaria, A. M. A. (2017). The degree of satisfaction of faculty members with the performance of scientific councils at the University of Najran, International Specialized Educational Journal, Volume 6, No. 10. P. 36-77. 